\title{
PERCEPTIONS OF PATIENTS ABOUT CATARACT
}

Regina de Souza Carvalho de Salles Oliveira, Edméa R. Temporini, Newton Kara José, Pedro C. Carricondo, and Andréa C. Kara José

Oliveira R de SC de S, Temporini ER, Kara-José N, Carricondo PC, Kara-José AC. Perceptions of patients about cataract. Clinics. 2005;60(6):455-60.

OBJECTIVE: To identify in adult patients suffering from cataract the perceptions regarding the disease and its surgical treatment. MATERIALS AND METHODS: An exploratory survey was conducted among adult patients suffering from cataract and participating in a large-scale cataract management program at the University of São Paulo General Hospital in 2004. The interviews were conducted by research assistants previously trained to pose questions and record answers.

RESULTS: The sample consisted of 170 men and women (43.5\% and 56.5\%, respectively), aged between 40 and 88 years. Of the 170 participants, $43.5 \%$ were from the State of São Paulo, $14.7 \%$ from the State of Bahia, $12.4 \%$ from the State of Minas Gerais, 5.9\% from the State of Pernambuco, 1.8\% from other countries, and the remaining $21.7 \%$ were from other Brazilian states. Of those who were actively working $(\mathrm{n}=87), 43.7 \%$ had an occupational level corresponding to nonspecialized manual labor, $27.6 \%$ were in specialized manual labor jobs, $25.3 \%$ had routine nonmanual occupations, $1.1 \%$ supervised manual labor, and $2.3 \%$ had low-ranking supervision or inspection jobs over nonmanual occupations. Of those who were not actively working $(\mathrm{n}=82), 53.6 \%$ were retired, $45.2 \%$ were housewives, and $1.2 \%$ were unemployed. Concerning conceptions about cataract, $79.0 \%$ referred to it as "a small skin fold that gradually covers the eye" and $32.4 \%$ mentioned, in addition, other conceptions. Concerning the cause, of the alternatives presented to them, $80 \%$ reported aging, $47.1 \%$ blamed "overusing the eyes in the workplace or at home", $7.1 \%$ believed they had cataract due to some kind of "spell." Of the associated answers, 94.1\% referred to "blurred vision" in people suffering from cataract, $72.4 \%$ thought the person may become blind, and $66.5 \%$ believed that the patients suffering from cataract are depressed because they cannot see. Regarding surgery, $28.8 \%$ were afraid of undergoing surgery; of those, $16.3 \%$ cited with the fear of dying during surgery, $55.1 \%$ thought they might become blind, $40.8 \%$ believed the surgery would be painful, and $8.2 \%$ followed religious practices that do not permit surgery.

CONCLUSION: Some misconceptions were identified, and the fear of blindness was the most mentioned reason for not seeking cataract surgery, which indicates the need for orientation.

KEYWORDS: Cataract. Surgery. Blindness. Vision. Perception.

Low visual acuity and blindness may have adverse consequences, both at individual and population levels. They lead to psychological, social, and economic problems and quality of life impairment, because they generate loss of self-esteem and of occupational status, with resulting loss of income. ${ }^{1}$

Department of Ophthalmology, Hospital das Clinicas, São Paulo University Medical School - São Paulo/SP, Brazil.

Faculty of Medicine, University of Campinas - Campinas/SP, Brazil.

Email: reso@uol.com.br

Received for publication on May 31, 2005.

Accepted for publication on September 17, 2005.
One of the causes of treatable blindness is cataract. According to a survey conducted in the early 1990s, an estimated 35,000 patients have cataract-related blindness in Brazil. ${ }^{2}$

Visual recovery of patients suffering from cataract is possible with outpatient-based surgical intervention, which is a quite safe procedure and is available in our country. Each year, an estimated 100,000 cataract surgeries are performed in Brazil, whereas the estimated demand is for 450,000 surgeries. ${ }^{3} \mathrm{~A}$ reason for concern is the predicted increase (3- to 5 -fold) of the population above 50 years by the year 2020, with a corresponding increase in the demand 
for cataract surgery. ${ }^{4}$

Nationwide programs for the prevention of visual loss, which include large-scale cataract surgery, have been implemented, with the objective of facilitating the access of the poor population to this form of treatment.

The project entitled "Cataract-free Zone" was a precursor of these programs. Having started at Campinas University in 1986, the project aimed at picturing the reality of the ophthalmologic care provided to poor people, assessing the feasibility of therapeutic alternatives consistent with local resources and the possible additional resources to be mobilized within the local limitations. ${ }^{2}$ The project expanded to the whole country in the form of large-scale cataract management programs.

In the city of São Paulo, the University of São Paulo Medical School General Hospital started to perform largescale cataract surgery in 1996, and the number of surgical procedures has significantly increased. ${ }^{4}$

However, monitoring progress in the assistance to poor patients requires regular surveys to measure the status of care. A more accurate knowledge of concepts, opinions, and doubts of subjects regarding cataract and surgery is a prerequisite for the development of educational programs that maay help in the quest for visual recovery. Conducting surveys also serves the purpose of assessing treatment feasibility, considering the local population's characteristics.

The "Cataract-free Zone" initiatives conducted in Campinas - SP (1986), in Botucatu - SP (1993), and in Ribeirão Preto - SP (1994) have shown that, despite the presence of university hospitals in these comparatively wealthy urban areas, a significant number of the patients with cataract-related visual deficits did not receive treatment, mainly due to socioeconomic and cultural barriers. ${ }^{2}$ It is essential to understand these barriers, especially those of a cultural nature, if we want to enhance people's ability to make decisions and to take the correct steps concerning ocular health.

The present study was conducted with the objective of identifying the perceptions of patients suffering from cataract regarding the disease and its surgical treatment, in order to provide healthcare professionals with support for future action.

\section{MATERIALS AND METHODS}

An exploratory survey was conducted among adult patients suffering from cataract and who participated in a large-scale cataract management program at the University of São Paulo General Hospital in July 2004.

A specially-designed questionnaire was administered during interviews conducted by research assistants trained for this purpose. Patients were informed about the study and could withdraw their free and informed consent to participate at any time.

The following inclusion criteria were defined:

Patients, both men and women, suffering from cataract were included in the large-scale management cataract program. Patients suffering from cataract and aged below 40 years were excluded from the study:.

The statistical analysis of the data was presented in tables as percentage values.

The study was approved by the Ethics Committee of the University of São Paulo.

\section{RESULTS}

The sample consisted of 170 men and women $(43.5 \%$ and $56.5 \%$, respectively) aged between 40 and 88 years. Of the 170 participants, $43.5 \%$ were from the State of São Paulo, $14.7 \%$ from the State of Bahia, $12.4 \%$ from the State of Minas Gerais, $5.9 \%$ from the State of Pernambuco, $1.8 \%$ from other countries, and the remaining $21.7 \%$ came from several other Brazilian states. The working population ( $\mathrm{n}$ $=87$ ), comprised 5 groups as follows: nonspecialized manual occupations, 43.7\%; specialized manual labor, $27.6 \%$; routine nonmanual occupations, $25.3 \%$; manual labor supervisors, $1.1 \%$; and low-ranking supervisors or inspectors of nonmanual occupations, $2.3 \%$.

Among those who were not actively working $(n=82)$, $53.6 \%$ were retired, $45.2 \%$ were housewives, and $1.2 \%$ were unemployed (Table 1).

Tabela 1 - Occupation $(\mathrm{n}=169 *)$

\begin{tabular}{lll}
\hline Active population & frequency & $\%$ \\
\hline yes & 87 & 51.5 \\
no & 82 & 48.5 \\
\hline Occupational level & \multicolumn{2}{c}{$(\mathrm{n}=87)$} \\
\hline Level I & 0 & 0 \\
Level II & 0 & 0 \\
Level III & 2 & 2.3 \\
Level IV & 22 & 25.3 \\
Level V & 1 & 1.1 \\
Level VI & 24 & 27.6 \\
Level VII & 38 & 43.7 \\
\hline
\end{tabular}

1 subject did not answer

Levels : I - Politicians and high-rank administrative officials; II - Liberal professions, directors, medium-sized company owners; III- Low-rank supervision/ inspection job over nonmanual occupations; small business owners, industry, farming and cattle breeding; IV- Routine nonmanual jobs and related; V - Supervision of manual jobs and related activities ;VI Specialized manual labor and related jobs; VII - Nonspecialized nonmanual jobs. Kara -Jr,N, Temporini,ER, Kara-José, N. Cataract Surgery: Expectations of patients assisted during a community project in São Paulo,state of São Paulo, Brazil. Rev. Hosp. Clin. Fac. Med. SP, 56(6):163168,2001 
Of the answers supplied in terms of conceptions about cataract, $79.0 \%$ referred to a "small skin fold that gradually covers the eye," and $32.4 \%$ mentioned, in addition, other concepts, such as eye aging, eye infection, and eye disease (Table 2).

Table 2 - Conceptions about cataract (associated answers)

\begin{tabular}{cccccc}
\hline \multicolumn{2}{c}{$\mathrm{n}=170$} & $\begin{array}{c}\text { Skin covering } \\
\text { the eyes }\end{array}$ & $\begin{array}{c}\text { Eye } \\
\text { aging }\end{array}$ & $\begin{array}{c}\text { Eye } \\
\text { infection }\end{array}$ & $\begin{array}{c}\text { Eye } \\
\text { disease }\end{array}$ \\
\hline 79 & 46.5 & 79 & & & \\
21 & 12.4 & 21 & 21 & & \\
10 & 5.9 & 10 & 10 & 10 & \\
7 & 4.1 & & 7 & & 7 \\
6 & 3.5 & 6 & 6 & 6 & 6 \\
6 & 3.5 & 6 & 6 & & 6 \\
5 & 2.9 & 5 & & 5 & 5 \\
4 & 2.4 & 4 & & 4 & \\
3 & 1.8 & 3 & & & 3 \\
3 & 1.8 & & 3 & &
\end{tabular}

The other subjects interviewed ( $15.3 \%$ ) supplied information on other forms of association, 1 subject each; 10 subjects did not provide information

Concerning the cause, of the alternatives presented to them, $80 \%$ reported aging, $47.1 \%$ blamed "overusing the eyes in the workplace or at home," $36.5 \%$ reported prolonged sun exposure, $30.0 \%$ reported an ocular accident, $30.0 \%$ reported prior systemic disorders, $37.6 \%$ reported genetic inheritance, $7.1 \%$ blamed excessive use of eyeglasses, $17.6 \%$ blamed the use of drugs or eye drops, and $7.1 \%$ believed they had cataract due to some kind of "spell" (Table 3).

Table 3 - Opinions relating to the causes of cataract $(\mathrm{n}=170)$

\begin{tabular}{lrrrrrr}
\hline Opinion & \multicolumn{2}{c}{ Yes } & \multicolumn{2}{c}{ No } & \multicolumn{2}{c}{ Does not know } \\
& $F^{*}$ & $\%$ & $F^{*}$ & $\%$ & $F^{*}$ & $\%$ \\
\hline Overused the eyes & 80 & 47.1 & 58 & 34.1 & 32 & 18.8 \\
( at work/ at home) & & & & & & \\
Prolonged sun exposure & 62 & 36.5 & 78 & 45.9 & 30 & 17.6 \\
Aging & 136 & 80.0 & 25 & 14.7 & 9 & 5.3 \\
Ocular accident & 51 & 30.0 & 94 & 55.3 & 25 & 14.7 \\
Prior disease & 51 & 30.0 & 86 & 50.6 & 33 & 19.4 \\
Genetic inheritance & 64 & 37.6 & 84 & 49.4 & 22 & 13.0 \\
Use of eyeglasses & 12 & 7.1 & 125 & 73.5 & 33 & 19.4 \\
Use of eye-drops/ drugs & 30 & 17.6 & 114 & 67.1 & 26 & 15.3 \\
Spell & 12 & 7.1 & 133 & 78.2 & 25 & 14.7
\end{tabular}

$\mathrm{F}^{*}$ - frequency

Of the associated answers, $94.1 \%$ reported "blurred vision" in people suffering from cataract, $72.4 \%$ thought the person may become blind, and $66.5 \%$ believed the patients suffering from cataract are depressed because they cannot see (Table 4). Regarding surgery, $28.8 \%$ were afraid of undergoing surgery (Table 5); of those, 16.3 cited the fear of dying during surgery, $55.1 \%$ thought they might become blind, $40.8 \%$ believed the surgery would be painful, $8.2 \%$ followed religious practices that forbid surgery, and $16.4 \%$ knew someone who underwent cataract surgery and had their vision worsened (Table 6).

Table 4 - Opinions related to the consequences of cataract $(\mathrm{n}=170)$

\begin{tabular}{|c|c|c|c|c|c|c|}
\hline \multirow[t]{2}{*}{ Opinion } & \multicolumn{2}{|c|}{ Yes } & \multicolumn{2}{|c|}{ No } & \multicolumn{2}{|c|}{ Does not know } \\
\hline & $\mathrm{F}^{*}$ & $\%$ & $\mathrm{~F}^{*}$ & $\%$ & $\mathrm{~F}^{*}$ & $\%$ \\
\hline Blurred vision & 160 & 94.1 & 4 & 2.4 & 6 & 3.5 \\
\hline Blindness & 123 & 72.4 & 26 & 15.3 & 21 & 12.3 \\
\hline Depression & 113 & 66.5 & 34 & 20.0 & 23 & 13.5 \\
\hline \multicolumn{7}{|l|}{$\mathrm{F}^{*}$ - frequency } \\
\hline \multicolumn{7}{|c|}{ Table 5 - Fear of surgery $\quad(n=170)$} \\
\hline Opinion & \multicolumn{4}{|c|}{ Frequency } & \multicolumn{2}{|c|}{$\%$} \\
\hline Yes & \multicolumn{4}{|c|}{49} & \multicolumn{2}{|c|}{28.8} \\
\hline No & \multicolumn{4}{|c|}{119} & \multicolumn{2}{|c|}{70.0} \\
\hline Does not know & \multicolumn{4}{|c|}{2} & \multicolumn{2}{|c|}{1.2} \\
\hline
\end{tabular}

Table 6 - Reasons for the fear of surgery (Affirmative answers)

\begin{tabular}{lrcc}
\hline Opinion & $\begin{array}{c}\text { Frequency } \\
(\mathrm{n}=49)\end{array}$ & $\begin{array}{c}\% \text { of the total } \\
(\mathrm{n}=170)\end{array}$ \\
\hline Fear of dying & 8 & 16.3 & 4.7 \\
May become blind & 27 & 55.1 & 15.9 \\
Knows someone who & 8 & 16.3 & 4.7 \\
$\begin{array}{l}\text { worsened after surgery } \\
\text { Religion forbids }\end{array}$ & 4 & 8.2 & 2.4 \\
Pain & 20 & 40.8 & 11.8 \\
\hline
\end{tabular}

\section{DISCUSSION}

Obtaining information on what people know and do in relation to ocular disorders is an important step in planning visual loss prevention programs, as well as for implementing healthcare measures. The prevalence of misconceptions about low visual acuity leads to possible misinformation about the chances of rehabilitation. This is confirmed when we observe that many people remain blind due to fear of undergoing surgery.

Studies conducted in Campinas (Brazil) and Chimbote (Peru) have concluded that in $30.0 \%$ of the cases of cataract-related blindness, the patients refused surgery, and the reasons alleged were fear of the surgical procedure and acceptance of blindness. ${ }^{7-9}$ A study about the perceptions of patients participating in a community-oriented visual rehabilitation project in an urban area in the state of São Paulo has found that the fear of cataract surgery, mentioned by $40.0 \%$ of the interviewed subjects, was linked to sup- 
posed consequences of the surgical procedure, i.e., visual loss and death. ${ }^{10}$

In this study, the fear of surgery was related to multiple reasons, such as the fear of becoming blind, feeling pain, dying, and even the fear of punishment, mentioned by patients whose religious practice forbids surgery (Tables 5 and 6 ).

The lack of information about senile cataract surgery leads people to believe they may die during the surgical procedure, when, in reality, this procedure is extremely unlikely to cause death. The fact that it is performed with local and/or topical anesthesia drastically reduces the risk of anaphylactic shock and wipes out anesthesia related death.

It seems evident that misconceptions and fatalistic attitudes account for behavioral patterns are important factors leading to cataract-related blindness, due to the lack of appropriate surgery.

It should be emphasized that cataract surgery is conditioned by some patient dependent factors: 1) reduced visual acuity; 2) subject's awareness about and agreement with respect to the existence of a manageable ocular disorder; 3 ) awareness of treatment availability and confidence in the recovery of visual capacity; 4) search for ophthalmologic care, which should be available; 5) acceptance of diagnosis and therapeutic approach; 6) presence of physical, psychological, and economic conditions as well as an appropriate family setup. ${ }^{11}$

After the patient becomes aware of the decrease in visual acuity, the next step is to gain understanding of the problem, so that its causes and consequences can be established on the short term, and the subject can seek visual rehabilitation and avoid becoming marginalized due to the visual deficit. The fact that many people relate cataract to false causes may decrease the search for surgical treatment. The belief that cataract is a consequence of aging may lead to a fatalistic attitude of helplessness with the acceptance of the process as one of natural organ decay. Temporini et al, in a survey conducted with patients from the large-scale cataract management program in Mogi-Guaçu, SP (Brazil), reported that senile cataract may be perceived by the public as an irreversible process for which "there is nothing we can do." They also observed that $43.1 \%$ of the surveyed population attributed their low visual acuity to the overuse of the eyes at work. ${ }^{10}$

In this study, $80.0 \%$ stated that cataract is caused by aging, and $47.1 \%$ said they believed the cause was the overuse of the eyes at work or in domestic chores. (Table 3). The concept that visual effort impairs vision is quite common among people of any socioeconomic status level. ${ }^{12}$

The belief that some form of "spell" might cause cataract $(7.1 \%)$ may lead the patient to search for inappropri- ate and ineffective forms of treatment based on cultural traditions. Large-scale cataract treatment initiatives are good sources of reference for surveys on behavioral patterns, beliefs, and attitudes.

The large-scale cataract programs conducted at the University of São Paulo General Hospital try to eliminate barriers and to provide the cataract patient with the necessary treatment by facilitating access to ophthalmologic examinations and surgery, in addition to providing education for the public. A significant fraction of the population seeks effective and free care at the University Hospital. The programs are also excellent sources of reference for the analysis of the pathways taken by the patients in their search for treatment.

In our sample, there was a slight predominance of women $(56.5 \%)$. A similar profile $(53.0 \%$ women) was found by Kara-José and Temporini in a study conducted in 5 urban areas in the state of São Paulo; ${ }^{1} 67 \%$ were women in a large-scale cataract program in the state of Pernambuco, in 2002.5 This predominance may be explained by the fact that in Brazil women have the role of caretakers of the family's health status.

The fact that $43.5 \%$ of participants were from São Paulo, where the project was carried out, while $56.5 \%$ came from other states indicates that the sample was heterogeneous concerning place of birth, which could perhaps be explained by a displacement of the patients towards the reference centers; alternatively, it could reflect the very high level of internal migration, mainly to São Paulo, prevalent during the latter part of the $20^{\text {th }}$ Century.

Kara-José Jr and Arieta, in a chapter about cataract, ${ }^{13}$ estimated the prevalence of senile cataract to be $17.6 \%$ for subjects below 65 years, $47.1 \%$ for those between 65 and 74 , and $73.3 \%$ for those above 75 years of age. In the present study, the highest rate of cataract, $41.7 \%$, was found between 70 and 88 years of age, which is similar to the Framingham findings ${ }^{14}$. It should be noted that the age group between 40 and 59 years is considered to be economically active, which suggests that subjects in this group might still be working, were it not for their low visual acuity. In our study, $48.5 \%$ of the participants were economically inactive (Table 1), with $53.6 \%$ of them being retired, $45.2 \%$ housewives, and $1.2 \%$ unemployed.

Of those actively participating in the labor force, $71.3 \%$ were in occupational levels VI and VII, which represent specialized and nonspecialized manual labor and similar jobs, and $25.3 \%$ were in level IV, representing routine nonmanual occupations and similar jobs. The classification of occupational levels was the same used by Kara-Junior et al in a survey of 331 subjects during the cataract project of 1999, where levels VI and VII were also predominant $(92.3 \%){ }^{6}$ 
Zacharias et al, in a survey conducted at the University of São Paulo General Hospital, within the context of the April 2000 "Cataract Project", found 70.9\% of the studied population to be economically inactive $(50.2 \%$ retired, $12.5 \%$ housewives, and $8.3 \%$ unemployed). ${ }^{4}$

Considering the scope of community-oriented initiatives conducted at university hospitals, where the healthcare services are focused on the poor population, it would have been reasonable to expect that the occupational level would relate to nonspecialized manual and nonmanual labor, such as clerk, dressmaker, gardener, driver, painter, doorkeeper, electrician, and others. However, we encoutered a generally higher level of Professional ranking in our population.

The most prevalent definition of cataract among the interviewed patients was "a small skin fold that covers the eye," with this answer appearing alone or in combination with other concepts (Table 2). This is a misconception probably due to confusion with pterygium, a more conspicuous disease, due to its external location. This misconception is revealed by the patients' verbatim statements: "I have been operated to scratch out the cataract," which in fact refers to pterygium. The surgery for correction of pterygium is more difficult and has a poorer prognosis than cataract surgery. The current prevalence of cataract exceeds that of pterygium, which is seen more often in the young population. In general, misconceptions about the results obtained with the surgery of pterygium may represent a barrier to the search for cataract treatment.

The results of this study increase our knowledge about people's information and beliefs, representing an important step in planning actions and programs with the goal of preventing visual loss.

If the healthcare providers intend to broaden the access of the public to cataract surgery, social and cultural barriers must be eliminated. Educating the public about cataract-what it is, what are its causes, its consequences. and its treatment-is an essential element of the so-called "cataract projects".

The results of this study indicate that the patients who participate in the large-scale cataract program of the University of São Paulo General Hospital have insufficient information about cataract. False and distorted conceptions about cataract point towards the need to develop orientation programs for the public. Such programs would arguably bring more people to the university centers, and these people would in all likelihood undergo surgery and recover their vision, their status of independence and an active participation in the labor market.

\section{ACKNOWLEDGEMENTS}

We are grateful to Claudia KJ Pinheiro, Dr. Paulo Cavalcante, Ricardo Versolato and all the Resident Physicians for their valuable help with data collection.

\section{RESUMO}

Oliveira R de SC de S, Temporini ER, Kara-José N, Carricondo PC, Kara-José AC. Percepções de pacientes sobre catarata. Clinics. 2005;60(6):455-60.

OBJETIVO: Identificar percepções de adultos portadores de catarata em relação à doença e ao tratamento cirúrgico. MATERIAIS E MÉTODOS: Foi realizada uma pesquisa exploratória entre pacientes adultos portadores de catarata presentes em mutirão em hospital universitário no ano de 2004. Auxiliares de pesquisa previamente treinados para formulação das questões e registros das respostas, encarregaram-se das entrevistas.

RESULTADOS: A amostra foi composta por 170 sujeitos de ambos os sexos (43,5\% do sexo masculino e $56,5 \%$ do sexo feminino) com idade entre 40 e 88 anos. Dos 170 participantes, 43,5\% eram nascidos no estado de São Paulo, $14,7 \%$ na Bahia, $12,4 \%$ em Minas Gerais, $1,8 \%$ nasceram em outros paises e os demais sujeitos, em outros estados brasileiros.Da população ativa no mercado de trabalho
( $\mathrm{n}=87$ ), encontravam-se em nível de ocupação manual não especializada $43,7 \%$; ocupação manual especializada $27,6 \%$; ocupação de rotina não manual $25,3 \%$; supervisão de trabalho manual $1,1 \%$; posição baixa de supervisão ou inspeção , considerando ocupações não manuais, $2,3 \%$. Entre a população inativa no mercado de trabalho $(\mathrm{n}=82), 53,6 \%$ eram aposentados, 45,2\% donas de casa e 1,2\% desempregados. Em relação a concepção sobre catarata, 79,0\% referiram ser uma "pelezinha que vai cobrindo os olhos" e 32,4\% além da "pelezinha", mencionaram outras concepções. Em relação a causa , entre as opções fornecidas, $80 \%$ relacionam a velhice; $47,1 \%$ "por usar muito as vistas no serviço ou em casa"; $7,1 \%$ acreditam que tem catarata devido a "mau olhado". Dentre as respostas associadas, 94,1\% referiram que a "visão fica embaçada" na pessoa que tem catarata, 72,4\% acham que a pessoa pode ficar cega e 66,5\% acham que os portadores de catarata ficam com depressão por não enxergarem. Vinte e oito por cento tem medo de se submeter a cirurgia, desses, $16,3 \%$ atribuem ao fato de poderem mor- 
rer na cirurgia; $55,1 \%$ acham que podem ficar cego; $40,8 \%$ crêem que a cirurgia dói e 8,2\% tem medo de operar pois a religião não permite.

CONCLUSÃO: Foram evidenciados alguns conhecimentos incorretos, o medo de ficar cego se fez presente entre as razões para não operar a catarata, indicando necessidade de provimento de orientação.

PALAVRAS-CHAVE: Catarata. Cirurgia. Cegueira. Visão. Percepção.

\section{REFERENCES}

1. Kara-José N,TemporiniER. Cirurgia de catarata :o porquê dos excluídos. Rev Panam Salud Publica/ Pan Am J Public Health. 1999;6(4):242-8.

2. Kara-José Jr N, Schellini AS, Silva MRBM, Bruni LF, Almeida AGC. Projeto Catarata. Qual a sua importância para a comunidade? Arq Bras Oftal. 1996;59(5):490-6.

3. Kara-José N, Delgado A, Arieta CEL. Catarata, in :Rodrigues MLV. Oftalmologia Clinica. Rio de Janeiro, Ed Cultura Médica 1992; p. 288302.

4. Zacharias LC, Graziano RM, Oliveira BFT, Hatanaka M, Cresta FB, Kara-José N. A campanha da catarata atrai pacientes da clinica privada? Arq Bras Oftal. 2004;65.

5. Ventura L, Brandi CT. Projeto Mutirão de catarata em centro de referência Oftalmológica, em Pernambuco: perfil, grau e satisfação e benefício visual do usuário. Arq Bras Oftal. 2004;67:231-5.

6. Kara Jr N, Temporini ER, Kara-José N. Cataract surgery: expectations of patients assisted during a community project in São Paulo, state of São Paulo, Brazil. Rev Hosp Clin Fac Med SP. 2001;56(6):163-8.

7. Kara-José N, Contreras F, Campos MA, Delgado AM, Mowery RL, Ellwein BL. Screening and surgical intervention results from cataractfree zone projects in Campinas, Brazil and Chimbote, Perú. International Ophthalmology. 1990;14:155-64.
8. Avakian A, Temporini ER, Kara-José N. Second eye cataract surgery: preceptions of a population assisted at a University Hospital. Clinics. 2005;60:401-6.

9. Carvalho KM, Monteiro GBM, Isaac CR, Shiroma LO, Amaral MS. Causes of low vision and use of optical aids in the elderly. Rev. Hosp. Clin. Fac. Med. S. Paulo. 2004;59:157-160.

10. Temporini ER, Kara-José N, Kara Jr N. Catarata senil: características e percepções de pacientes atendidos em projeto comunitário de reabilitação visual. Arq Bras Oftalm. 1997;60(1):79-83.

11. Kara-José N, Arieta CEL, Temporini ER, Kang KM, Ambrósio LE. Tratamento cirúrgico de catarata senil: óbices para o paciente. Arq Bras Oftal. 1996;59(6):573-7.

12. Kara-José N, Oliveira RCS. Olhos-mitos . Ed Contexto, São Paulo, 1991.

13. Kara Jr N, Arieta CEL. Catarata Senil. in Kara-José N, Almeida GV. Senilidade Ocular, Ed Roca, São Paulo, 2001; p. 98-107.

14. Kahn HA, Leibowitz HM, Ganley JP, Kini MM, Colton T, Nickerson RS, Dawber TR.The Framingham Eye Study. II. Association of ophthalmic pathology with single variables previously measured in the Framingham Heart Study. Am J Epidemiol. 1977 106:33-41. 